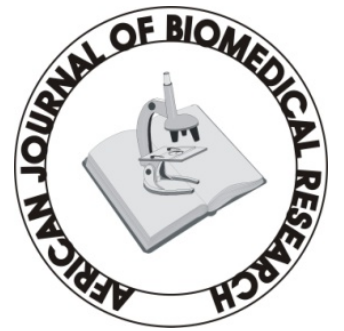

Full-text available at http://www.ajbrui.com http://www.bioline.br/md http://www.ajol.com

Received:

March 2008

Accepted (Revised):

May 2008

Published

May 2008
Full Length Research Article

\section{Anthropometric and Biochemical Profiles of Black South African Women}

\author{
${ }^{1}$ Hattingh Z, ${ }^{2}$ Walsh C.M, ${ }^{3}$ Veldman F.J, ${ }^{4}$ Bester C.J, \\ ${ }^{5}$ Oguntibeju 0.0
}

${ }^{1}$ School of Tourism, Hospitality and Sport, Central University of Technology, Free State; ${ }^{2}$ Department of Nutrition and Dietetics, University of the Free State;

${ }^{3}$ School of Health Technology, Central University of Technology, Free State;

${ }^{4}$ Department of Biostatistics, University of the Free State;

Department of Biomedical Sciences, Faculty of Health \& Wellness Sciences, Cape

Peninsula University of Technology, Bellville, South Africa

\begin{abstract}
It has been reported that the diet of rural women in most African countries differs considerably from that of their urban counterparts, with the urban diet composed of more refined carbohydrates and fatty food. This study examines anthropometric and biochemical profiles and the association between these parameters in pre-menopausal, post-pubertal black South African women. A representative sample of 500 participants, randomly selected in Mangaung, Bloemfontein in the Free State Province, using township maps obtained from the Bloemfontein Municipality were recruited to participate. Younger women were aged 25-34 years and older women 3544 years. Anthropometric and biochemical profiles were determined according to standard methods. From the original sample of 500 women, 496 were eligible to participate. Of the younger women $30.1 \%$ and of the older women $27.7 \%$ were overweight, while $23.3 \%$ of younger women and $24 \%$ of older women had a body mass index (BMI) $\geq 30 \mathrm{~kg} / \mathrm{m}^{2}$, indicating obesity. Most women had a waist-hip ratio (WHR) $<0.8$, indicating gynoid fat distribution. The majority of women from both age groups had a body fat percentage $>25 \%$ ( $92.5 \%$ and $94 \%$ respectively of younger and older women). Of the younger women $6.8 \%$ and of the older women $13.8 \%$ had triglyceride (TG) levels higher than the reference range. Total cholesterol levels fell within the reference range for $79.8 \%$ of the younger women and $71.3 \%$ of the older women. Glucose and insulin levels were within reference ranges for most women of both age groups. A significant association was found between insulin sensitivity and BMI and between insulin sensitivity and TG levels in both age groups. No significant association was found between waist circumference and elevated glucose levels in both age groups. A significant difference between insulin sensitivity and WHR was observed in the older group of women. The prevalence of overweight and obesity reported in this population may pose a potential risk for the development of chronic diseases such as type 2 diabetes.
\end{abstract}

Keywords: Black women, anthropometric indicators, biochemical parameters, obesity, type 2 diabetes mellitus

*Author for correspondence:Tel: +17584546128, Fax:+17584546811, Email:bejufemi@yahoo.co.uk

Abstracted by:

African Index Medicus (WHO), CAB Abstracts, Index Copernicus, Global Health Abstracts, Asian Science Index, Index

Veterinarius, Bioline International , African Journals online 


\section{INTRODUCTION}

The universal movement of concurrent changes in dietary structure and physical activity patterns, referred to as "the nutrition transition", is reflected in nutritional outcomes, including changes in body composition. These shifts coincide with major conversions in the general health profile (Popkin, 2006) of especially middle- and lower-income communities (Kim et al., 2000).

With the nutrition transition, populations tend to move away from traditional food practices towards the consumption of diets higher in energy (Compher, 2006), more diverse diets, and the consumption of more refined grains, saturated fat and sugar (Popkin, 1994). Literature indicates that South African and other population groups who formed part of the nutrition transition have become increasingly vulnerable to developing chronic diseases (Compher, 2006; Steyn et al., 1997; Drewnowski \& Popkin, 1997; Temple et al., 2001; Macintyre et al., 2002) such as obesity, type 2 diabetes mellitus, and cardiovascular disease. Albertse, Neethling and De Villiers (1990) reported that the diet of rural Zulu women in South Africa differs considerably from that of urban Zulu women, with the rural diet composed of $69 \%$ carbohydrates, $17 \%$ fat, $13 \%$ protein and $37 \mathrm{~g}$ of fibre per day, compared with $50 \%$ carbohydrates, $31 \%$ fat, $16 \%$ protein and $14 \mathrm{~g}$ of fibre in the daily diet of urban Zulu women. This places urban black South African women at higher risk for developing obesity and type 2 diabetes mellitus or other chronic diseases - hence the urgent need to assess the anthropometric and biochemical profile of South African women living in Mangaung, the urban black township of Bloemfontein in the Free State Province.

\section{SUBJECTS AND METHODS}

Population and sampling: A representative sample of 500 women from two formal settlements (Phahameng and Botchabela) and two informal settlements (Joe Slovo and Namibia) in Mangaung, the black residential township of Bloemfontein (capital city of the Free State Province), was randomly selected to participate in the study.

Post-pubertal but pre-menopausal black women were randomly selected from the two age groups 25-34 and 35-44 years using township maps. The residential plots in the four selected areas were counted and numbered. Namibia consisted of 2 995 plots, Pahameng 1 711, Joe Slovo 1 359, and Botchabela 2 308. A proportionate number of respondents were randomly selected from these settlements. Twenty subjects were recruited per week over a 25-week period (March 2000 November 2000). A randomly selected residence was approached by a trained community healthcare worker. One woman per selected residence was screened for eligibility. If nobody was home, the residence to the right was targeted and, if still unsuccessful, the residence to the left of the original address was approached. If all attempts failed, another plot was randomly selected. The assigned community health workers explained the purpose of the study to possible participants. The women took part voluntarily, after giving written informed consent. The informed consent document was approved by the Ethics Committee of the Faculty of Health Sciences, University of the Free State (ETOVS no. 02/00).

Respondents fasted overnight, abstained from exercise, and avoided consuming alcohol and caffeine for 24 hours prior to anthropometric measurement and the collection of blood samples. All blood samples were taken in the morning. Three interpreters were available to assist researchers where language problems were encountered. Each participant was examined by a medical practitioner.

Anthropometric measurements: Anthropometric measurements were performed by a qualified anthropometrist. Weight was determined with a "Seca" digital electronic scale, to the nearest 0.1 $\mathrm{kg}$, with the participant dressed in light clothing. Height, determined with a stadiometer to the nearest $0.1 \mathrm{~cm}$, body mass index (BMI) calculated from body weight and height in metres squared, and waist-hip ratio (WHR) calculated from waist circumference and hip circumference were 
determined according to standard methods (Lee \& Nieman, 1996; Hammond, 2000). Bioelectrical impedance analysis was used to determine body composition for fat (Bodystat, 2000) according to cut-off points (Smolin \& Grosvenor, 2003).

Blood sampling and analysis: Blood samples from the participants, who had fasted overnight, were collected by a qualified nursing sister and were used to determine fasting triglycerides (TGs), fasting total cholesterol, fasting serum albumin, fasting serum glucose and fasting serum insulin levels. Ten millilitres of whole blood were left to clot at room temperature. These samples were centrifuged at $3360 \mathrm{rpm}$ for 20 minutes to allow the serum to separate. Serum samples were frozen at $-72^{\circ} \mathrm{C}$ in Eppendorf ${ }^{\mathrm{R}}$ vials for later analysis. Fasting TGs were determined using the GPO-PAP method, total cholesterol using the CHOD-PAP method, serum albumin using a colorimetric endpoint method, and glucose using an enzymatic colorimetric method (supplied by Roche Diagnostics, GmbH, Mannheim, Germany). Serum insulin was determined by the DRG insulin ELISA, a solid-phase two-site enzyme immunoassay. Insulin sensitivity was calculated using the formula: $10000 /$ (glucose $\mathrm{x}$ insulin) (Donahue et al., 1988).

\section{Statistical analysis}

The data was categorised into the age groups 2534 years and 35-44 years. For each group, medians or percentiles were described by applying continuous variables. Categorical variables were described using percentages. BMI, WHR and fat percentage were calculated and categorised according to the cut-off points. For each group, the categorised variables were described using percentages. The association between waist circumference and glucose levels was determined as described by Newcombe (1998). The association between BMI and TG levels was determined by Spearman rank order correlations.

\section{RESULTS}

From the original sample of 500 women, 496 women qualified to participate. Of those who qualified, 279 were aged 25-34 years and 217 were aged 35-44 years. Four women were found to be pregnant during the medical examination and were excluded from the study.

Anthropometric indicators:BMI values of both age groups are presented in Table 1. More than half of the women in both age groups had a BMI $\geq 25 \mathrm{~kg} / \mathrm{m}^{2}$. More women in the younger group had a BMI within the reference value. In the younger group $30.1 \%$ of women were overweight, while $27.7 \%$ of the older women were overweight. Twenty-three percent of the younger women and $24 \%$ of the older women had a BMI $\geq 30 \mathrm{~kg} / \mathrm{m}^{2}$, indicating obesity.

The WHR of both age groups is presented in Table 2. Most women in both age groups had a WHR below 0.8, indicating gynoid fat distribution. Of the younger women $83.5 \%$ had a WHR below $0.8 \%$, while this applied to $62.7 \%$ of the older women. The majority of subjects had a fat percentage higher than the recommended range of $20-25 \%$ (92.5\% of the younger group and $94 \%$ of the older group) (Table 3 ).

Table 1: BMI of the two age groups (25-34 and 35-44 years)

\begin{tabular}{|l|l|l|l|l|l|l|l|l|l|l|}
\hline Age group & \multicolumn{10}{|c|}{ BMI category $\left(\mathrm{kg} / \mathrm{m}^{2}\right)$} \\
\hline & $<18.5$ & $18.5<20$ & $20<25$ & $25<30$ & $\geq 30$ \\
\hline \multirow{2}{*}{$25-34$ years } & $\mathrm{N}$ & $\%$ & $\mathrm{~N}$ & $\%$ & $\mathrm{~N}$ & $\%$ & $\mathrm{~N}$ & $\%$ & $\mathrm{~N}$ & $\%$ \\
\cline { 2 - 12 } & 7 & 2.5 & 14 & 5 & 109 & 39.1 & 84 & 30.1 & 65 & 23.3 \\
\hline \multirow{3}{*}{$35-44$ years } & $\mathrm{N}$ & $\%$ & $\mathrm{~N}$ & $\%$ & $\mathrm{~N}$ & $\%$ & $\mathrm{~N}$ & $\%$ & $\mathrm{~N}$ & $\%$ \\
& & & & & & & & & \\
\cline { 2 - 12 } & 9 & 4.1 & 17 & 7.8 & 79 & 36.4 & 60 & 27.7 & 52 & 24 \\
\hline
\end{tabular}

Key: $<18.5 \mathrm{~kg} / \mathrm{m}^{2}$ (underweight), $18.5<20 \mathrm{~kg} / \mathrm{m}^{2}$ (lower weight), $20<25 \mathrm{~kg} / \mathrm{m}^{2}$ (normal weight), $25<30 \mathrm{~kg} / \mathrm{m}^{2}$ (overweight), $\geq 30 \mathrm{~kg} / \mathrm{m}^{2}$ (obese) 


\section{Biochemical parameters}

Of the younger group $93.2 \%$ and of the older group $86.2 \%$ had fasting TG levels within the normal value $(<2 \mathrm{mmol} / \mathrm{l})$, while $6.8 \%$ of the younger women and $13.8 \%$ of the older women had TG levels $\geq 2 \mathrm{mmol} / \mathrm{l}$. Fasting cholesterol levels fell within the reference value $(>0.9<5.2$ $\mathrm{mmol} / \mathrm{l}$ ) for $79.8 \%$ of younger women and $71.3 \%$ of older women, while $15.9 \%$ of younger women and $27.8 \%$ of older women fell within the moderate risk group $(5.2<7.8 \mathrm{mmol} / \mathrm{l})$. On the whole, the percentage of women in the high-risk category $(\geq 7.8 \mathrm{mmol} / \mathrm{l})$ for cholesterol was relatively low (4.3\% of younger women and $0.9 \%$ of older women). A higher percentage of women in both groups (98.6\% of younger women and $99.5 \%$ of older women) had normal (34-48 g/l) serum albumin levels. Fasting serum glucose levels were within the reference range (3.05 - 6.38 $\mathrm{mmol} / \mathrm{l}$ ) for most women in the two age groups (84.1\% of younger women and $89.9 \%$ of older women). More women in the younger group than in the older group demonstrated high fasting serum glucose levels $(10.5 \%$ and $4.2 \%$ respectively). Results showed that the majority of women had serum insulin levels within the reference range $(<25 \mu \mathrm{U} / \mathrm{ml})$. Results of the biochemical parameters indicated that most women in the two age groups had fasting TG, albumin, glucose and insulin levels within reference ranges.

The 25 percentile (Q1), 50 percentile (medianQ2) and 75 percentile (Q3) values of biochemical parameters of the two age groups of women are presented in Table 4 and Table 5.

Associations between fasting glucose and waist circumference, BMI and TG, insulin sensitivity and BMI, and insulin sensitivity and TG were determined. No significant associations were found between waist circumference and fasting glucose (Table 6) and between TG and BMI in both groups (Table 7). For insulin sensitivity (25-34 age group), the number of women in each group ranged from 68 in group 1 to 69 in groups 2, 3 and 4 . In group 1, with the lowest insulin sensitivity (highest insulin resistance), the median BMI was $27.6 \mathrm{~kg} / \mathrm{m}^{2}$. As insulin sensitivity improved, the median BMI decreased (groups 1 to 4). Group 4, the most insulin-sensitive group (lowest insulin resistance), reported the lowest median BMI $\left(23 \mathrm{~kg} / \mathrm{m}^{2}\right)$. When the medians of BMI were compared between all groups by 95\% non-parametric confidence interval (CI), significant differences were found between BMI and insulin sensitivity of groups 1 and 4, groups 2 and 4, and groups 3 and 4 (Table 8).

Table 2:

WHR of the two age groups (25-34 and 35-44 years)

\begin{tabular}{|l|l|l|l|l|}
\hline \multirow{2}{*}{ Age group } & \multicolumn{4}{|c|}{ WHR } \\
\cline { 2 - 5 } & $<0.8$ & \multicolumn{4}{|c|}{} & $\mathrm{N} .8$ \\
\hline \multirow{2}{*}{$25-34$ years } & $\mathrm{N}$ & $\%$ & $\mathrm{~N}$ & $\%$ \\
\cline { 2 - 5 } & 233 & 83.5 & 46 & 16.5 \\
\hline \multirow{3}{3}{$35-44$ years } & $\mathrm{N}$ & $\%$ & $\mathrm{~N}$ & $\%$ \\
\cline { 2 - 5 } & 136 & 62.7 & 81 & 37.3 \\
\hline
\end{tabular}

Table 3:

Fat percentage of the two age groups (25-34 and 35-44 years)

\begin{tabular}{|l|l|l|l|l|l|l|}
\hline $\begin{array}{l}\text { Age } \\
\text { group }\end{array}$ & \multicolumn{2}{|l|}{$<20 \%$} & \multicolumn{2}{l|}{$20 \leq 25 \%$} & \multicolumn{2}{l|}{$>25 \%$} \\
\hline $\begin{array}{l}25-34 \\
\text { years }\end{array}$ & $\mathrm{N}$ & $\%$ & $\mathrm{~N}$ & $\%$ & $\mathrm{~N}$ & $\%$ \\
\cline { 2 - 8 } & 3 & 1.1 & 18 & 6.5 & 258 & 92.5 \\
\hline $\begin{array}{l}35-44 \\
\text { years }\end{array}$ & $\mathrm{N}$ & $\%$ & $\mathrm{~N}$ & $\%$ & $\mathrm{~N}$ & $\%$ \\
\cline { 2 - 8 } & 3 & 1.4 & 10 & 4.6 & 204 & 94 \\
\hline
\end{tabular}

Key:

$<20 \%$ (low fat percentage), $20 \leq 25 \%$ (normal fat percentage), $>25 \%$ (high fat percentage)

Table 4:

Biochemical parameters of age group 25-34 years

\begin{tabular}{|l|l|l|l|l|}
\hline \multirow{2}{*}{$\begin{array}{l}\text { Biochemical } \\
\text { parameters }\end{array}$} & \multicolumn{4}{|l|}{ Age group 25-34 years } \\
\cline { 2 - 5 } $\begin{array}{l}\text { Fasting blood } \\
\text { glucose (mmol/l) }\end{array}$ & 276 & 3.9 & 4.3 & 4.7 \\
\hline Serum insulin $\mu \mathrm{U} / \mathrm{ml}$ & 276 & 3.0 & 7.0 & 15.5 \\
\hline Insulin sensitivity & 275 & 144.5 & 325.3 & 755.3 \\
\hline $\begin{array}{l}\text { Total cholesterol } \\
(\mathrm{mmol} / \mathrm{l})\end{array}$ & 277 & 3.6 & 4.2 & 4.9 \\
\hline TG (mmol/l) & 277 & 0.7 & 0.9 & 1.2 \\
\hline Albumin $(\mathrm{g} / \mathrm{l})$ & 277 & 38.8 & 41.3 & 44.3 \\
\hline
\end{tabular}

Key: Q1 (25 percentile), Q2 (50 percentile), Q3 (75 percentile) 
Table 5: Biochemical parameters of age group 35-44 years

\begin{tabular}{|l|l|l|l|l|}
\hline \multirow{2}{*}{$\begin{array}{l}\text { Biochemical } \\
\text { parameters }\end{array}$} & \multicolumn{4}{|l|}{ Age group 35-44 years } \\
\cline { 2 - 5 } $\begin{array}{l}\text { Fasting blood } \\
\text { glucose (mmol/l) }\end{array}$ & 217 & 4 & 4.4 & 4.9 \\
\hline Serum insulin $\mu \mathrm{U} / \mathrm{ml}$ & 217 & 2.5 & 6.3 & 10.7 \\
\hline Insulin sensitivity & 217 & 206 & 390.4 & 977.5 \\
\hline $\begin{array}{l}\text { Total cholesterol } \\
(\mathrm{mmol} / \mathrm{l})\end{array}$ & 216 & 3.9 & 4.5 & 5.3 \\
\hline TG (mmol/l) & 216 & 0.8 & 1.1 & 1.5 \\
\hline Albumin (g/l) & 215 & 38.9 & 41.5 & 43.6 \\
\hline
\end{tabular}

Key: Q1 (25 percentile), Q2 (50 percentile), Q3 (75 percentile)

Table 6: Association between fasting glucose and waist circumference

\begin{tabular}{|l|c|c|}
\hline Parameter & $<35$ years & $\geq 35$ years \\
\cline { 2 - 3 } & No \& \% & No \& \% *I \\
\hline $\begin{array}{l}\text { Waist circumference }<0.88 \\
\text { cm \& glucose }>\text { normal }\end{array}$ & $21(72.4)$ & $5(55.6)$ \\
\hline $\begin{array}{l}\text { Waist circumference } \geq 0.88 \\
\text { cm \& glucose }>\text { normal }\end{array}$ & $5(27.6)$ & $4(44.4)$ \\
\hline $\begin{array}{l}\text { 95\% CI for difference } \\
\text { between \% }\end{array}$ & $\begin{array}{l}(-3.67 ; \\
17.5)^{*}\end{array}$ & $\begin{array}{l}(-2.7 ; \\
11.6)^{*}\end{array}$ \\
\hline
\end{tabular}

*Insignificant difference between fasting glucose and waist circumference

In the age group 35-44 years, the number of subjects in each group ranged from 53 in group 2 and 54 in group 3, to 55 in groups 1 and 4 . In group 1, with the lowest insulin sensitivity, the median BMI was $26.2 \mathrm{~kg} / \mathrm{m}^{2}$ while in group 4 , the most insulin-sensitive group, the median BMI was $23.5 \mathrm{~kg} / \mathrm{m}^{2}$. Significant differences were found between BMI and insulin sensitivity of groups 1 and 4, groups 2 and 4, and groups 3 and 4 (Table 9).

Table 7: Association between BMI and TG

\begin{tabular}{|c|c|c|c|c|}
\hline \multirow{2}{*}{$\begin{array}{l}\text { BMI } \\
\text { category }\end{array}$} & \multicolumn{2}{|l|}{$<35$ years } & \multicolumn{2}{|c|}{$\geq 35$ years } \\
\hline & $\begin{array}{l}\text { Normal } \\
\text { TG }\end{array}$ & $\begin{array}{l}\text { High } \\
\text { TG }\end{array}$ & $\begin{array}{l}\text { Normal } \\
\text { TG }\end{array}$ & High TG \\
\hline $\begin{array}{l}\mathrm{BMI}<18 \\
.5\end{array}$ & $6(85.7 \%)$ & $\begin{array}{l}1(14.3 \\
\%)\end{array}$ & $9(100 \%)$ & $0(0 \%)$ \\
\hline $\begin{array}{l}\text { BMI } \\
18.5<25\end{array}$ & $\begin{array}{l}\text { 118(97.5 } \\
\%)\end{array}$ & $3(2.5)$ & $\begin{array}{l}85(88.5 \\
\%)\end{array}$ & $\begin{array}{l}\text { 11(11.5 } \\
\%)\end{array}$ \\
\hline $\begin{array}{l}\text { BMI } \\
25<30\end{array}$ & 77(93.9\% & $5(6.1 \%$ & $\begin{array}{l}50(83.3 \\
\%)\end{array}$ & $10(16.7)$ \\
\hline $\begin{array}{l}\text { BMI } \\
\geq 30\end{array}$ & $\begin{array}{l}57(89.1 \% \\
)\end{array}$ & $\begin{array}{l}7(10.9 \\
\%)\end{array}$ & $\begin{array}{l}\text { 43(82.7 } \\
\%)\end{array}$ & $\begin{array}{l}9(17.3 \% \\
)\end{array}$ \\
\hline
\end{tabular}

When the medians of WHR were compared between all insulin-sensitive groups by $95 \%$ nonparametric CI for the median difference, a significant difference was found between groups 1 and 4 of the older women (Table 11). When the medians of TG were compared with all insulinsensitive groups, a significant difference was found between groups 1 and 3 and between groups 1 and 4 within the age group 25-34 years (Table 12).

Table 8:

Association between BMI and insulin sensitivity in age group 25-34 years

\begin{tabular}{|c|c|c|c|c|}
\hline Parameter & $\begin{array}{l}\text { Insulin sens } 1 \\
12.13 \leq 144.47\end{array}$ & $\begin{array}{l}\text { Insulin sens } 2 \\
>144.47 \leq 325.28\end{array}$ & $\begin{array}{l}\text { Insulin sens } 3 \\
>325.28 \leq 755.34\end{array}$ & $\begin{array}{l}\text { Insulin sens } 4 \\
>755.34\end{array}$ \\
\hline BMI & 68 & 69 & 69 & 69 \\
\hline Median & 27.6 & 26.7 & 26.3 & 23.0 \\
\hline \multirow[t]{7}{*}{ BMI } & \multicolumn{2}{|c|}{ Median difference } & \multicolumn{2}{|c|}{ 95\% non-parametric CI } \\
\hline & Gp 1-2 & 0.5 & \multicolumn{2}{|l|}{$-1.33 ; 2.28$} \\
\hline & Gp 1-3 & 0.6 & \multicolumn{2}{|l|}{$-1.26 ; 2.48$} \\
\hline & Gp 1-4 & 3.5 & \multicolumn{2}{|l|}{$1.91 ; 5.38 *$} \\
\hline & Gp 2-3 & 0.1 & \multicolumn{2}{|l|}{$-1.73 ; 1.87$} \\
\hline & Gp 2-4 & 3.1 & \multirow{2}{*}{\multicolumn{2}{|c|}{$1.40 ; 4.73^{*}$}} \\
\hline & Gp 3-4 & 2.9 & & \\
\hline
\end{tabular}

*Values with the same symbol differ significantly between groups

- $\quad$ Sens= sensitivity

- $\mathrm{Gp}=$ (group) 
Table 9:

Association between BMI and insulin sensitivity in age group 35-44 years

\begin{tabular}{|c|c|c|c|c|}
\hline Parameter & $\begin{array}{l}\text { Insulin sens } 1 \\
14.10 \leq 206.01\end{array}$ & $\begin{array}{l}\text { Insulin sens } 2 \\
>206.01 \leq 309.39\end{array}$ & $\begin{array}{l}\text { Insulin sens } 3 \\
>309.39 \leq 977.52\end{array}$ & $\begin{array}{l}\text { Insulin sens } 4 \\
>977.52\end{array}$ \\
\hline BMI (No) & 55 & 53 & 54 & 55 \\
\hline Median & 26.2 & 26 & 26.5 & 23.5 \\
\hline \multirow[t]{2}{*}{ BMI } & \multicolumn{2}{|c|}{ Median difference } & \multicolumn{2}{|c|}{ 95\% non-parametric CI } \\
\hline & $\begin{array}{l}\text { Gp 1-2 } \\
\text { Gp 1-3 } \\
\text { Gp 1-4 } \\
\text { Gp 2-3 } \\
\text { Gp 2-4 } \\
\text { Gp 3-4 }\end{array}$ & $\begin{array}{l}0.6 \\
-0.1 \\
3.2 \\
-0.4 \\
2.8 \\
3.3\end{array}$ & \multicolumn{2}{|l|}{$\begin{array}{l}-1.80 ; 2.87 \\
-2.20 ; 2.23 \\
1.24 ; 5.27^{*} \\
-2.81 ; 1.60 \\
0.79 ; 4.88^{*} \\
1.60 ; 5.24^{*}\end{array}$} \\
\hline
\end{tabular}

*Values with the same symbol differ significantly between groups

$\mathrm{Gp}=$ group Sens=sensitivity

Table 10:

Association between WHR and insulin sensitivity in age group 25-34 years

\begin{tabular}{|c|c|c|c|c|}
\hline Parameter & $\begin{array}{l}\text { Insulin sens } 1 \\
12.13 \leq 144.47 \\
\end{array}$ & $\begin{array}{l}\text { Insulin sens } 2 \\
>144.47 \leq 325.28\end{array}$ & $\begin{array}{l}\text { Insulin sens } 3 \\
>325.28 \leq 755.34 \\
\end{array}$ & $\begin{array}{l}\text { Insulin sens } 4 \\
>755.34 \\
\end{array}$ \\
\hline $\begin{array}{l}\text { WHR } \\
\text { No }\end{array}$ & 68 & 69 & 69 & 69 \\
\hline Median & 0.74 & 0.73 & 0.74 & 0.74 \\
\hline \multirow[t]{2}{*}{ WHR } & \multicolumn{2}{|c|}{ Median difference } & \multicolumn{2}{|c|}{ 95\% non-parametric CI } \\
\hline & $\begin{array}{l}\text { Gp 1-2 } \\
\text { Gp 1-3 } \\
\text { Gp 1-4 } \\
\text { Gp 2-3 } \\
\text { Gp 2-4 } \\
\text { Gp 3-4 }\end{array}$ & $\begin{array}{l}0.002 \\
0.02 \\
0.01 \\
0.01 \\
0.01 \\
-0.002\end{array}$ & \multicolumn{2}{|l|}{$\begin{array}{l}-0.02 ; 0.03 \\
-0.01 ; 0.04 \\
-0.01 ; 0.03 \\
-0.02 ; 0.04 \\
-0.01 ; 0.02 \\
-0.02 ; 0.02\end{array}$} \\
\hline
\end{tabular}

Gp=group Sens=sensitivity

Table 11:

Association between WHR and insulin sensitivity in age group 35-44 years

\begin{tabular}{|c|c|c|c|c|}
\hline Parameter & $\begin{array}{l}\text { Insulin sens } 1 \\
14.10 \leq 206.01\end{array}$ & $\begin{array}{l}\text { Insulin sens } 2 \\
>206.01 \leq 390.39\end{array}$ & $\begin{array}{l}\text { Insulin sens } 3 \\
>390.39 \leq 977.52\end{array}$ & $\begin{array}{l}\text { Insulin sens } 4 \\
>977.52\end{array}$ \\
\hline $\begin{array}{l}\text { WHR } \\
\text { No }\end{array}$ & 55 & 53 & 54 & 55 \\
\hline Median & 0.79 & 0.78 & 0.77 & 0.76 \\
\hline \multirow[t]{2}{*}{ WHR } & \multicolumn{2}{|c|}{ Median difference } & \multicolumn{2}{|c|}{ 95\% non-parametric CI } \\
\hline & $\begin{array}{l}\text { Gp 1-2 } \\
\text { Gp 1-3 } \\
\text { Gp 1-4 } \\
\text { Gp 2-3 } \\
\text { Gp 2-4 } \\
\text { Gp 3-4 }\end{array}$ & $\begin{array}{l}0.002 \\
0.02 \\
0.03 \\
0.01 \\
0.01 \\
-0.002 \\
\end{array}$ & \multicolumn{2}{|l|}{$\begin{array}{l}-0.01 ; 0.04 \\
-0.001 ; 0.05 \\
0.001 ; 0.06^{*} \\
-0.02 ; 0.04 \\
-0.01 ; 0.04 \\
-0.02 ; 0.03\end{array}$} \\
\hline
\end{tabular}

$*$ Values with the same symbol differ significantly between groups

$\mathrm{Gp}=$ group Sens=sensitivity 
Table 12:

Association between TG and insulin sensitivity in age group 25-34 years

\begin{tabular}{|c|c|c|c|c|}
\hline Parameter & $\begin{array}{l}\text { Insulin sens } 1 \\
12.13 \leq 144.47\end{array}$ & $\begin{array}{l}\text { Insulin sens } 2 \\
>144.47 \leq 325.28\end{array}$ & $\begin{array}{l}\text { Insulin sens } 3 \\
>325.28 \leq 755.34\end{array}$ & $\begin{array}{l}\text { Insulin sens } 4 \\
>755.34\end{array}$ \\
\hline $\begin{array}{l}\text { TG } \\
\text { No }\end{array}$ & 68 & 69 & 69 & 69 \\
\hline Median & 1.1 & 0.92 & 0.83 & 0.91 \\
\hline \multirow[t]{2}{*}{ TG } & \multicolumn{2}{|c|}{ Median difference } & \multicolumn{2}{|c|}{ 95\% non-parametric CI } \\
\hline & $\begin{array}{l}\text { Gp 1-2 } \\
\text { Gp 1-3 } \\
\text { Gp 1-4 } \\
\text { Gp 2-3 } \\
\text { Gp 2-4 } \\
\text { Gp 3-4 } \\
\end{array}$ & $\begin{array}{l}0.1 \\
0.2 \\
0.2 \\
0.1 \\
0.02 \\
-0.05 \\
\end{array}$ & \multicolumn{2}{|l|}{$\begin{array}{l}-0.01 ; 0.3 \\
0.06 ; 0.39 * \\
0.01 ; 0.32 * \\
-0.05 ; 0.2 \\
-0.11 ; 0.1 \\
-0.2 ; 0.1\end{array}$} \\
\hline
\end{tabular}

*Values with the same symbol differ significantly between groups

$\mathrm{Gp}=$ group

Sens=sensitivity

Table 13:

Association between TG and insulin sensitivity in age group 35-44 years

\begin{tabular}{|c|c|c|c|c|}
\hline Parameter & $\begin{array}{l}\text { Insulin sens } 1 \\
14.10 \leq 206.01\end{array}$ & $\begin{array}{l}\text { Insulin sens } 2 \\
>206.01 \leq 390.39\end{array}$ & $\begin{array}{l}\text { Insulin sens } 3 \\
>390.39 \leq 977.52\end{array}$ & $\begin{array}{l}\text { Insulin sens } 4 \\
>977.52\end{array}$ \\
\hline $\begin{array}{l}\text { TG } \\
\text { No }\end{array}$ & 55 & 52 & 54 & 55 \\
\hline Median & 1.3 & 0.98 & 1.1 & 1.1 \\
\hline \multirow[t]{2}{*}{ TG } & \multicolumn{2}{|c|}{ Median difference } & \multicolumn{2}{|c|}{ 95\% non-parametric CI } \\
\hline & $\begin{array}{l}\text { Gp 1-2 } \\
\text { Gp 1-3 } \\
\text { Gp 1-4 } \\
\text { Gp 2-3 } \\
\text { Gp 2-4 } \\
\text { Gp 3-4 } \\
\end{array}$ & $\begin{array}{l}0.22 \\
0.14 \\
0.2 \\
-0.1 \\
-0.01 \\
0.06 \\
\end{array}$ & \multicolumn{2}{|l|}{$\begin{array}{l}0.03 ; 0.4^{*} \\
-0.06 ; 0.34 \\
0.02 ; 0.40^{*} \\
-0.3 ; 0.1 \\
-0.1 ; 0.2 \\
-0.1 ; 0.2\end{array}$} \\
\hline
\end{tabular}

*Values with the same symbol differ significantly between groups

$\mathrm{Gp}=$ group Sens=sensitivity

Within the age group 35-44 years, when the medians of TG were compared with those of all insulin-sensitive groups, a significant difference was found between groups 1 and 2 and between groups 1 and 4 (Table 13). Significant associations between insulin sensitivity and BMI and between insulin sensitivity and TG levels were found in this population. No associations were found between fasting glucose levels and waist circumference. The association between insulin sensitivity and WHR in the age group 25-34 years was not significant.

\section{DISCUSSION}

Urbanisation and lower physical activity levels, amongst other things, are associated with the increasing prevalence rates of obesity in Southern Africa (Walker et al., 2001), probably explaining the noticeable prevalence of overweight and obesity in the studied population. About $50 \%$ of all women demonstrated a BMI $\geq 25 \mathrm{~kg} / \mathrm{m}^{2}$, with $30.1 \%$ of younger women and $27.7 \%$ of older women falling into the overweight category. Results from South African studies conducted in 
recent years have indicated relatively high prevalence rates of overweight and obesity, particularly in the black population. The South African Demographic and Health Survey, a national cross-sectional study conducted in rural and urban areas in the nine provinces, revealed that $29.2 \%$ of male participants and $56.6 \%$ of female participants were overweight or obese. Of the black women, $31.8 \%$ were obese, $26.7 \%$ were overweight and $43.4 \%$ had abdominal obesity (Puoane et al., 2002). In a study conducted in a partly rural and urban black area in the Free State Province, South Africa, prevalence rates of obesity in this population ranged between $27.5 \%$ and $49 \%$ for women in QwaQwa (partially rural area) and between $31.1 \%$ and $54.3 \%$ for women in Mangaung (urban area). The authors of that survey warned that urgent measures were necessary to prevent an epidemic of atherosclerotic disease in the black population (Mollentze et al., 1995). Although the results from the present study indicated lower prevalence rates of obesity than the last-mentioned study, the percentage of women falling into the overweight category should be a matter of concern, as overweight may eventually lead to obesity and might pose a potential risk for developing type 2 diabetes or cardiovascular diseases. In the Transition and Health during Urbanisation of South Africans (THUSA) study conducted among black women living in the North West Province of South Africa, $25.2 \%$ of subjects were overweight and $28.6 \%$ were obese. BMI also correlated significantly with diastolic blood pressure, serum triacylglycerols, fasting glucose and log fasting insulin (Kruger et al., 2001).

In this study, most women in both age groups had a WHR below 0.8 . This value may increase if the respondents in this study do not control their dietary intake and increase their levels of physical activity. Mollentze et al., 1995) noted that a subgroup of obese persons with central or android obesity is at greater risk of developing cardiovascular disease. Results of WHR in this study (mean WHR of 0.74 in the younger group and 0.78 in the older group) were lower than the mean WHR of women in both populations studied by the last-mentioned authors, and for all age groups, which exceeded 0.8 [18], indicating a greater risk of developing cardiovascular disease and type 2 diabetes. Another study conducted among urban blacks in Cape Town showed a mean WHR of 0.8 for women older than 30 years (Levitt et al., 1993). A mean WHR of 0.8 for healthy, obese white and black South African women, with no significant differences found between these groups and between diabetic white and diabetic black women, was also reported previously (Van der Merwe et al., 1999). For individual respondents with a high WHR, an increase in physical activity could possibly have a favourable effect on body fat distribution, resulting in a reduction in the WHR and lower body obesity.

A matter of concern is the total number of women who demonstrated a significantly high body fat percentage. Regardless of weight, almost all the women that participated in this study had a fat percentage higher than the recommended value. Results from the present study show that the levels of physical activity in women were very low, coupled with the consumption of a high-energy diet and high macronutrient intake (Hattingh et al., 2006). Exercise in itself may not produce major weight losses, but exercise along with regulated dietary intake and lifestyle could help to alter the body composition favourably, reducing fat and increasing muscle mass (Caterson, 1998).

In this study, most of the women in the two age groups had normal fasting TG levels, but the higher percentage of older women with increased fasting TG levels calls for constant evaluation and monitoring. It has been shown that increased TG levels are associated with diet, alcohol consumption, obesity, and underlying or untreated diabetes mellitus, while weight loss, a lowsaturated-fat or low-cholesterol diet, increased physical activity, smoking cessation and restricted alcohol use could assist in lowering high TG levels Krummel, 2000).

A large percentage of women showed fasting cholesterol levels within the reference range. However, about $28 \%$ of the older women fell in 
the moderate risk group. It has been found that total cholesterol concentrations in blacks increase with age (Kruger et al., 2001), possibly explaining the $28 \%$ of older women falling into the moderate risk group for increased total cholesterol in the present study. However, mean cholesterol and saturated fat intakes in an earlier study of ours (Hattingh et al., 2006) also exceeded recommendations, and could possibly contribute to this. Total cholesterol levels in the study by Mollentze et al. (1995) indicated that urban participants had a greater tendency towards higher cholesterol levels than rural participants. Increased cholesterol levels are usually associated with a diet high in saturated fat and animal products. The large number of subjects in the moderate risk group was also a disturbing factor in the study of Mollentze et al. (1995), as is the case in this study.

For most women in the two age groups, fasting blood glucose levels fell within the reference range. Of the younger women $10.5 \%$ and of the older women $4.2 \%$ had blood glucose levels above the reference level. Raised blood glucose levels are commonly associated with the risk of developing type 2 diabetes. It is known that in some population groups, there has been an increase in the prevalence of type 2 diabetes associated with either migration or a rapid change from a traditional lifestyle to one characterised by increased consumption of energy-dense foods high in fat and sugars, as well as reduced levels of physical activity (Mann, 1998). A study investigating the prevalence of type 2 diabetes among urban blacks in the greater Cape Town area found a $7 \%$ prevalence rate of impaired glucose tolerance and an $8 \%$ prevalence rate of type 2 diabetes after being age adjusted (Levitt et al., 1993). Results from a study to determine the prevalence of type 2 diabetes and risk factors in Mamre, a peri-urban area near Cape Town composed primarily of descendants of the Khoi people (an indigenous population of South Africa), indicated an age-adjusted prevalence rate of $10.8 \%$ for type 2 diabetes and $10.2 \%$ for impaired glucose tolerance. The authors concluded that potentially modifiable risk factors included upper- segment fat distribution and physical inactivity (Levitt et al., 1999). In the study by Mollentze et al. (1995) the prevalence rates of type 2 diabetes were 6\% (Mangaung) and 4.8\% (QwaQwa) and were more frequently observed in men $>45$ years and in women $>35$ years. The fact that younger women in our study had been living in an urban area for a mean of 15 years and older women for a mean of 19 years indicates that urbanisation could possibly have had an influence on the glucose profiles of those women with high glucose levels. However, factors such as obesity, age and physical inactivity could also have played a role in this regard. In particular, the higher percentage of younger women with increased glucose levels possibly shows that the younger urbanised women had to a greater extent adopted a more Westernised diet than their older counterparts. Insulin resistance refers to an impaired biologic response to either exogenous or endogenous insulin. Both insulin resistance and insulin deficiencies are usual causes of type 2 diabetes (Franz, 2000). Glucose is the major regulator of insulin secretion, and the pancreas is sensitive to changes in glucose at physiological concentrations. In individuals with normal glucose tolerance, fasting plasma glucose levels are maintained by a complex interaction between hepatic glucose disposal and peripheral tissue glucose uptake. Downward regulation of plasma glucose entirely depends on circulating plasma insulin that enhances the uptake of glucose by the peripheral tissues. Impaired glucose tolerance, characterised by fasting hyperglycaemia, is largely due to increased glucagon secretion and the inability of the beta cells to secrete sufficient insulin, but is partly due to insulin resistance (Makuyana et al., 1999). In this study, 12\% of younger women and $10.6 \%$ of older women had insulin levels greater than the reference value. The implication is that these groups of women are more likely to present with insulin resistance. For the women with high insulin levels, both genetic and lifestyle factors may play a role (Franz, 2000) although our study and other South African studies have tended to favour lifestyle factors. Intake of excessive kilojoules, physical inactivity and obesity are believed to increase insulin resistance 
(Franz, 2000), and all these have been documented in black South African women.

The association between anthropometric and biochemical profiles is discussed in the subsequent section. The use of waist circumference has been suggested as a good indicator of fasting blood glucose (Okosun et al., 1998). Obese black women with a waist measurement $\geq 0.88 \mathrm{~cm}$ are considered to be at higher risk of developing chronic diseases (James, 2001). In this study, however, no significant association between waist circumference and elevated glucose levels was observed. The small percentage of women with elevated glucose levels makes statistical analysis of data difficult. Also, no significant association was reported between TG levels and BMI.

In black women, obesity is characterised by a decrease in insulin sensitivity and lower pancreatic beta cell function, probably explaining the increased prevalence of type 2 diabetes mellitus in these South Africans (Van der Merwe et al., 2000). An association between BMI and insulin sensitivity was observed in our study, with respondents within the two age groups with the lowest insulin sensitivity also having the highest mean BMI, while insulin sensitivity improved as BMI decreased. A reduction in BMI per se could therefore have beneficial effects on the health of these black women, regardless of fat distribution. High intakes of dietary fats may decrease insulin sensitivity in individuals already at increased risk for insulin resistance due to obesity and a sedentary lifestyle (Mayer-Davis et al., 1997).

It has been suggested that WHR circumference is a significant predictor of plasma TG, glucose and insulin concentrations and that it is correlated positively with an in vivo index of insulin resistance (Evans et al., 1984). A significant difference between WHR and insulin sensitivity was found in the insulin sensitivity of groups 1 and 4 of the older women. In the younger women, WHR showed no significant association with insulin sensitivity. Insulin is the major determinant and stimulant of lipoprotein lipase, an enzyme system responsible for the peripheral catabolism of triglyceride-rich lipoproteins. It is likely that the enhancement of insulin sensitivity would lead to a more efficient lipolytic system with a consequent decrease in the TG concentration of the individual (Donahue et al., 1988). It is suggested that an increase in physical activity can have beneficial effects on the TG profile and insulin sensitivity (Mayer-Davis et al., 1997) of the women who participated in this study.

\section{Conclusion}

The prevalence of overweight in the studied population was high. Although the prevalence of obesity in this study was lower than the rate reported in some other studies, the percentage of women who are overweight is a matter of concern, as a $B M I \geq 25 \mathrm{~kg} / \mathrm{m}^{2}$ is associated with adverse health consequences. The association between insulin sensitivity and BMI indicates that a large proportion of women are at risk of developing hyperinsulineamia as their BMI increases, which in turn could enhance the risk for obesity and type 2 diabetes. It is believed that the prevalence of overweight, obesity and high body fat percentage reported in this population may be associated with a diet that is high in energy and fat content and which may pose a risk for the development of cardiovascular diseases.

\section{Acknowledgements}

The National Research Foundation is acknowledged for financial support of this study. The authors would like to thank the women who participated in the study, the community health workers for contacting the sample, and the research team who collected the data.

\section{REFERENCES}

Albertse EC, Neethling A, De Villiers MA (1990): Diet and lifestyle differences between rural and urban Zulu women. South African $J$ Food Sc \& Nutr. 2(1): 1-2.

Caterson I (1998):. Overweight and obesity. In: J Mann \& AS Truswell (Eds.). Essentials of human nutrition. Oxford: Oxford University Press.

Compher C (2006):. The nutrition transition in American Indians. Journal of Transcultural Nursing. 17(3): 217-223. 
Donahue RP, Orchard TJ, Becker DJ, Kuller LH, Drash AL (1988): Physical activity, insulin sensitivity, and the lipoprotein profile in young adults: The Beaver County study. Am J Epidemiology. 127(1): 95-103.

Drewnowski A, Popkin BM (1997): The nutrition transition: New trends in the global diet. Nutrition Reviews. 55(2): 31-43.

Evans DJ, Hoffman RG, Kalkhoff RK, Kissebah AH (1984): Relationship of body fat topography to insulin sensitivity and metabolic profiles in premenopausal women. Metabolism. 33(1): 68-75.

Franz MJ (2000): Medical nutrition therapy for diabetes mellitus and hypoglycemia of nondiabetic origin. In: LK Mahan \& S Escott-Stump (Eds.). Krause's food, nutrition and diet therapy. Tenth edition. Philadelphia: WB Saunders Company.

Hammond KA (2000): Dietary and clinical assessment. In: LK Mahan \& S Escott-Stump (Eds.). Krause's food, nutrition and diet therapy. Tenth edition. Philadelphia: W.B. Saunders Company.

Hattingh Z, Walsh CM, Veldman FJ, Bester CJ (2006): Macronutrient intake of HIVseropositive women in Mangaung, South Africa. Nutrition Research. 26: 53-58.

James WPT. (2001): A modern approach to obesity management. Continuing Medical Education. 19(8): 558-564.

Kim S, Moon S, Popkin BM 2000. The nutrition transition in South Korea. Am J Clin Nutr. 71: 4453.

Kruger HS, Venter CS, Vorster HH (2001):

Obesity in African women in the North West

Province, South Africa is associated with an increased risk of non-communicable diseases: The THUSA study. Br J Nutr. 86(6): 733-740.

Krummel D (2000). Nutrition in cardiovascular disease. In: LK Mahan \& S Escott-Stump (Eds.). Krause's food, nutrition and diet therapy. Tenth edition. Philadelphia: WB Saunders Co.

Lee RD, Nieman DC (1996): Nutritional assessment. Second edition. New York: McGraw Hill Companies.

Levitt NS, Steyn K, Lambert EV, Reagon G, Lombard CJ, Fourie JM, Rossouw K, Hoffmann M (1999): Modifiable risk factors for type 2 diabetes mellitus in a peri-urban community in South Africa. Diabetic Medicine. 16: 946-950. Levitt, NS, Katzenellenbogen JM, Bradshaw D, Hoffman MN, Bonnici F (1993): The prevalence and identification of risk factors for NIDDM in urban Africans in Cape Town, South Africa. Diabetes Care. 16(4): 601-607.

Macintyre UE, Kruger HS, Venter CS, Vorster HH (2002): Dietary intakes of an African population in different stages of transition in the North West Province, South Africa: The THUSA study. Nutrition Research. 22: 239-256.

Makuyana D, Mahomed K, Ndlovu S, Mawji KGD, Siziya S (1999): Insulin secretion, clearance and sensitivity in black pregnant and non-pregnant women in Harare, Zimbabwe. Cent African J Med. 45(1): 11-14.

Mann J (1998): Diabetes mellitus. In: J Mann \& AS Truswell (Eds.). Essentials of human nutrition. Oxford: Oxford University Press. Mayer-Davis EJ, Monaco, JH, Hoen HM, Carmichael S, Vitrolies MA, Rewers MJ, Hafner SM, Ayad MF, Bergran RN, Karts AJ (1997). Dietary fat and insulin sensitivity in a triethnic population: The role of obesity - The Insulin Resistance Atherosclerosis Study (IRAS). Am J Clin Nutr. 65(1): 79-87.

Mollentze WF, Moore AJ, Steyn AF, Joubert G, Steyn K, Oosthuizen GM, Weich DJ (1995). Coronary heart disease risk factors in a rural and urban Orange Free State black population. South African Med J. 85(2): 90-96.

Newcombe RG (1998): Interval estimation for the difference between independent proportions: A comparative evaluation of eleven methods. Statistics in Med. 17(8): 873-890.

Okusun IS, Cooper RS, Rotimi CN, Osotimehin B, Forrester T (1998): Association of waist circumference with risk of hypertension and type 2 diabetes in Nigerians, Jamaicans, and AfricanAmericans. Diabetes Care. 21(11): 1836-1842.

Popkin BM (1994): The nutrition transition in low-income countries: An emerging crisis. Nutrition Reviews. 52(9): 285-298.

Popkin M (2006): Global nutrition dynamics The world is shifting rapidly toward a diet linked with noncommunicable diseases. Am J Clin Nutr. 84(2): 289-298. 
Puoane T, Steyn K, Bradshaw D, Laubscher R, Fourie J, Lambert V, Mbananga N 2002.

Obesity in South Africa: The South African Demographic and Health Survey. Obesity

Research. 10(10): 1038-1048.

Smolin LA, Grosvenor MB (2003): Nutrition science and applications. Fourth edition. New York: John Wiley \& Sons, Inc.

Steyn K, Katzenellenbogen JM, Lombard CJ, Bourne LT (1997):. Urbanization and the risk for chronic diseases of lifestyle in the black population of the Cape Peninsula, South Africa. $J$ Cardiovasc Risk. 4(2): 135-142.

Temple NJ, Steyn K, Hoffman M, Levitt NS, Lombard CJ (2002): The epidemic of obesity in South Africa: A study in a disadvantaged community. Ethn Disease. 11(3): 431-437. Van der Merwe MT, Crowther NJ, Schlaphoff GP, Gray IP, Joffe BI, Lönnroth PN (2000). Evidence for insulin resistance in black women from South Africa. Int $J$ Obes Relat Metab Disord. 24(10): 1340-1346.

Van der Merwe MT, Panz VR, Crowther NJ, Schlaphoff GP, Gray IP, Froguel P, Joffe BE, Lönnroth PN (1999): Free fatty acids and insulin levels: Relationship to leptin levels and body composition in various patient groups from South Africa. Int J Obesity. 23(9): 909-917. Walker ARP, Adam F, Walker BF (2001): World pandemic of obesity: The situation in Southern African populations. Public Health. 115(6): 368-372. 